\title{
ジメチルエーテル推進剤を用いた平行平板型パルスプラズマ推進機*1 A Parallel-Plate Pulsed Plasma Thruster Using a Dimethyl Ether Propellant
}

\author{
増 井 創 一*2 · 各 務聡*3 ·橘武 史*4 \\ Souichi Masui, Akira KaKAmi and Takeshi TACHIBANA
}

Key Words : Pulsed Plasma Thruster, Dimethyl Ether, Parallel-Plate

\begin{abstract}
Use of liquid propellants, such as water or ethanol, as an alternative to the most common propellant, solid Teflon, for a pulsed plasma thruster (PPT) is reported to improve the performance of PPT by excluding the drawbacks of uncontrollable propellant feed rate and timing, while maintaining the advantages of digital control features. In this study, we propose to use dimethyl ether (DME) as for the liquid propellant PPT, because DME has a low freezing point ( $131 \mathrm{~K}$ at standard pressure) and an expedient vapor pressure (6 atm at standard temperature), both of which eliminate the need for a heater and pressurant when using a water or ethanol propellant. A series of experiments using a prototype DME-PPT with parallel-plate electrodes demonstrated reliable operation with a tendency for the electromagnetic impulse bit $I_{\mathrm{bit}}$ to increase in proportion to the stored capacitor energy $E_{\mathrm{c}}$ up to $I_{\mathrm{bit}}=53 \mu \mathrm{Ns}$ at $E_{\mathrm{c}}=13 \mathrm{~J}$.
\end{abstract}

\section{記 号 の 説 明}

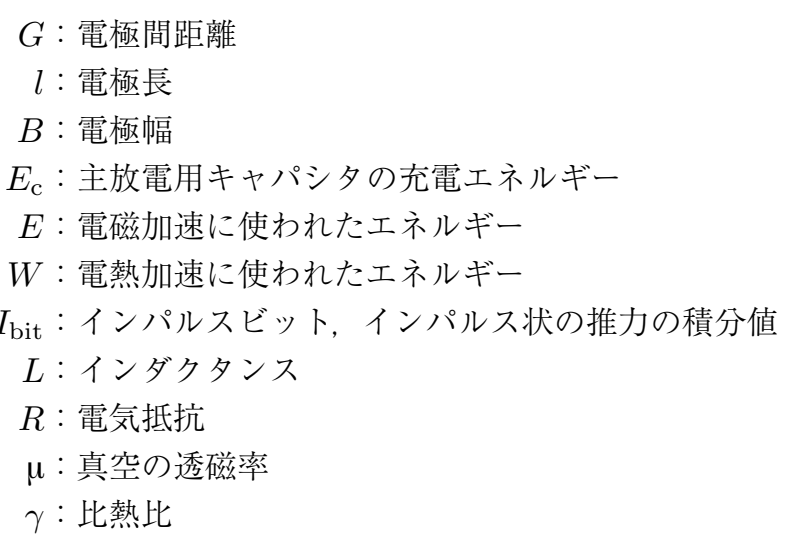

1.は じめ に

パルス型プラズマスラスタ（Pulsed Plasma Thruster, PPT）は小型・軽量で低消費電力作動が可能な宇宙用推進 機で，パルス駆動によるデジタル制御ができるという特徴 を有しており, 小型人工衛星の姿勢制御などに利用されてい る1,2). しかし従来のPPTでは，推進剤としてテフロン ${ }^{\circledR}$ に代表される固体推進剤が用いられていることに起因する “Late-time ablation”や "Particulate emission”などの現 象が発生し, 推進剂利用効率が低くなることが指摘されて おり，これが他の電気推進機に比べ推進性能が低くなる原 因となっている3). 前者は, パルスアーク放電終了後も固体

\footnotetext{
*1 (C) 2013 日本航空宇宙学会

平成 24 年 7 月 3 日原稿受付

*2 九州工業大学大学院工学研究府機械知能工学研究専攻

*3 宮崎大学工学部機械設計システム工学科

*4 九州工業大学大学院工学研究院機械知能工学研究系
}

推進剂の表面温度が昇華温度よりも高いため昇華した推進 剂が放電による加速を受けないまま流出し推力に寄与せず 損失となる現象, 後者は, パルスアーク放電中または終了 後にテフロンの表面から推力に寄与しない低速な固体粒子 が流出する現象である。また,これらの現象のほかに, 推 進剤の供給が放電による熱を利用しているため, 推進剤の 供給量を放電エネルギーと独立的に変化させることができ ないことも，比推力を向上させ難い要因となっている.

上記の問題を解消するために，液体を推進剤として用いる PPT (Liquid Propellant Pulsed Plasma Thruster, LPPPT) が提案されている. LP-PPTでは, 放電と推進剤の 供給を独立して制御でき, 推進剤の供給量も任意に設定で きるため, パルスアーク放電直前に適量の推進剂液滴を専 用の噴射器を用いて供給することにより, “Late-time ablation”や “Particulate emission”などが回避され推進剂利 用効率の向上につながる. また, 推進剤の供給量と放電エネ ルギーは独立しており, 推進剤供給量を固定したまま充電 エネルギーだけを増加することが可能となり, 比推力の向上 も可能となる。推進剤としてエタノールを用いた LP-PPT において, キャパシタの充電エネルギー $20 \mathrm{~J}$ 時に, 比推力 $4300 \mathrm{~s}$, 推進効率 $13 \%$ とテフロンを用いた PPT と比べて 高い性能を得ることが報告されている4).

しかし, これまで推進剤として試みられた水やエタノール では以下のような問題がある. 水は, 凝固点が常圧で $273 \mathrm{~K}$ と高いために，宇宙空間において液体として貯蔵するには ヒーターなどで温度管理を行う必要がある。また，水，エ 夕ノールの蒸気圧は常温でそれぞれ $2 \mathrm{kPa}, 6 \mathrm{kPa}$ である ため, 推進剤をタンクから供給するには加圧機構が必要と なり, 推進機全体の質量増大や大型・複雑化してしまうこ 
とが問題となる。

そこで本研究では, 推進剂としてジメチルエーテル (Dimethyl Ether, DME) を用いたPPT（以下 DME-PPT と表記）を提案する ${ }^{5)}$. DME は, 構造式が $\mathrm{CH}_{3}-\mathrm{O}-\mathrm{CH}_{3}$ の無毒なエーテル化合物である. DMEの凝固点は常圧で $125 \mathrm{~K}$ なので, 宇宙空間においても液体として貯蔵するこ とが容易である。また, DMEの蒸気圧は常温で $600 \mathrm{kPa}$ と適度に高く, 自身の蒸気圧により供給することが可能で ある。

本報では, 平行平板型 DME-PPT を試作し, その作動 を実証するとともに，推力の測定を行い性能評価を行った ので，それらの結果について報告する。

\section{2. 実 験 装 置}

2.1 自発放電方式の平行平板型 DME-PPT 第 1 図 に試作した平行平板型 DME-PPT の概略図を, 第 1 表に 実験条件を示す。この試作機では，供給した DME が電極 間で蒸発し電極間圧力を上昇させることにより，イグナイ 夕を使わずに自発的にパルスアーク放電を誘起する．放電 用の電極は, 紙面垂直方向に幅 $B$ が $10 \mathrm{~mm}$ のステンレス である，実験は，電極間距離 $G$ は $10 \mathrm{~mm}$ とし電極の長さ $l$ を $40,70,100 \mathrm{~mm}$ と変化させた場合と, 電極の長さ $l$ を $40 \mathrm{~mm}$ とし電極間距離 $G$ を $10,20,30 \mathrm{~mm}$ と変化させた 場合で行った，噴射器と電極との絶縁を行うために, 平行平 板電極と噴射器の間には, 厚さ $5 \mathrm{~mm}$ のセラミックプレー トを配置している. DMEは, 試作した電磁バルブ方式の噴

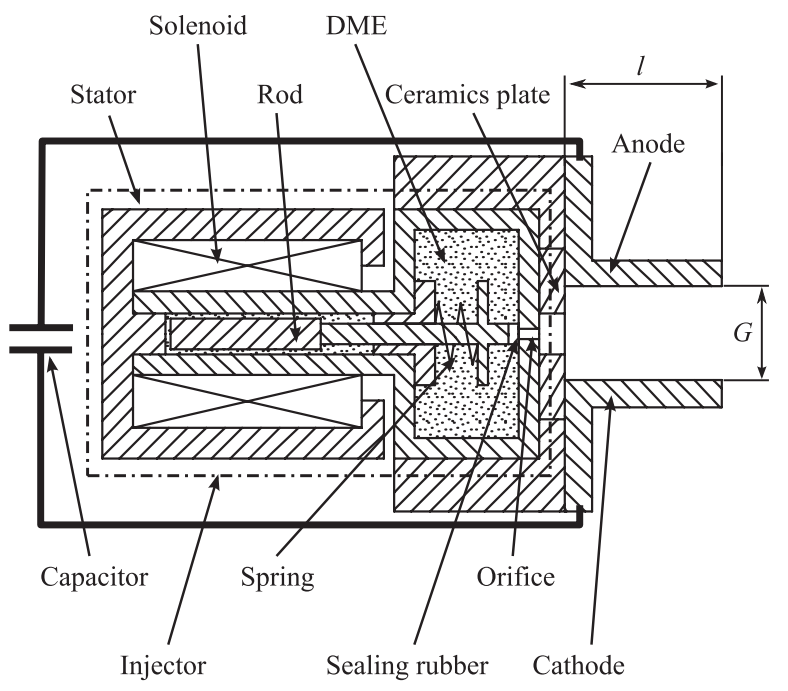

第 1 図 自発放電方式の平行平板型 DME-PPT

第 1 表 自発放電方式の平行平板型 DME-PPT の実験条件

\begin{tabular}{lccccc}
\hline 電極番号 & 1 & 2 & 3 & 4 & 5 \\
電極間距離 $G, \mathrm{~mm}$ & 10 & 10 & 10 & 20 & 30 \\
電極長さ $l, \mathrm{~mm}$ & 100 & 70 & 40 & 40 & 40 \\
電極幅 $B, \mathrm{~mm}$ & & & 10 & & \\
DME の噴射量 $\Delta m, \mu \mathrm{g}$ & \multicolumn{5}{c}{25} \\
充電エネルギー $E_{\mathrm{c}}, \mathrm{J}$ & \multicolumn{5}{c}{13} \\
\hline
\end{tabular}

射器により供給した。この噴射器は, 数十 $\mu \mathrm{g}$ オーダーでの 噴射を可能にするために, DMEのタンクと電磁バルブの 磁気回路を一体化させることによりダイアフラムなどを廃 した構造となっている. 噴射器の噴射口は約 $30 \mu \mathrm{m}$ であり, 1 回の噴射で 5〜 50 $\mu \mathrm{g}$ の範囲の DME を供給できる。ロッ ド先端にはシール材を使用しており, 噴射口と接すること により DMEの流出を防いでいる。現状でのリーク量の算 出のためにDME を充填した噴射器を真空中環境下に推力 と噴射量との測定実験時間に相当する 5 時間放置したとこ ろ, 噴射器の重量減少は $0.02 \mathrm{~g}$ であった。 1 回あたりの噴 射量 $\Delta m$ の目標值が約 $25 \mu \mathrm{g}$, 総噴射回数が 20000 回と設 定した場合で総噴射量は $0.5 \mathrm{~g}$ 程度なのでリークによる影響 は $4 \%$ 程度である。なお, 充電エネルギー $E_{\mathrm{c}}$ は, $1 \sim 13 \mathrm{~J}$ の範囲で実験を行った。

2.2 イグナイタ方式の平行平板型 DME-PPT 第 1 罒の装置に，強制的に放電を誘起させるためにイグナイ夕 を取り付けた平行平板型 DME-PPT でも同様な実験を行っ た。取り付けたイグナイタプラグ周辺の拡大した概略図を 第 2 図に示す。また実験条件を第 2 表に示す。イグナイタ を用いることにより，自発放電を誘起できない充電エネル ギー領域でもパルスアーク放電を誘起できる。噴射器など は自発放電方式の DME-PPT と同じである。電極間距離 $G$ と電極長さ $l$ はそれぞれ $30 \mathrm{~mm}, 40 \mathrm{~mm}$ とし，噴射量 $\Delta m$ は自発放電を誘起できない $25 \mu \mathrm{g}$ とした。 イグナイタ プラグの芯線は, 直径が $1 \mathrm{~mm}$ のタングステンの線であり, セラミックスプレートから $20 \mathrm{~mm}$ 離れた陰極側に固定し ている，芯線の先端位置は，陰極端面から $15 \mathrm{~mm}$ で，陰極

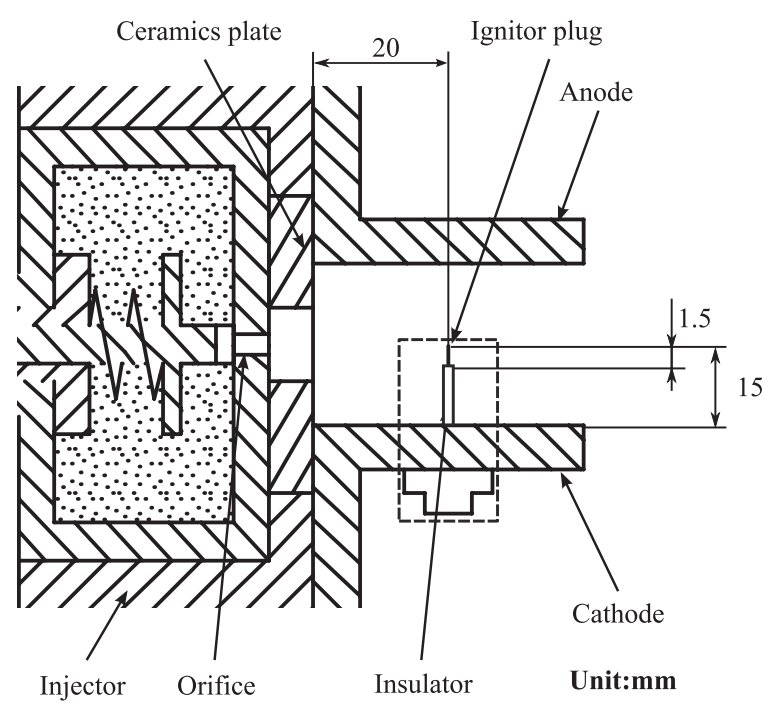

第 2 図 イグナイタプラグ周辺の拡大図

第 2 表 イグナイタ方式の平行平板型 DME-PPT の実験条件

\begin{tabular}{lc}
\hline 電極間距離 $G, \mathrm{~mm}$ & 30 \\
電極長さ $l, \mathrm{~mm}$ & 40 \\
電極幅 $B, \mathrm{~mm}$ & 10 \\
$\mathrm{DME}$ の噴射量 $\Delta m, \mu \mathrm{g}$ & 25 \\
充電エネルギー $E_{\mathrm{c}}, \mathrm{J}$ & $1 \sim 13$ \\
\hline
\end{tabular}




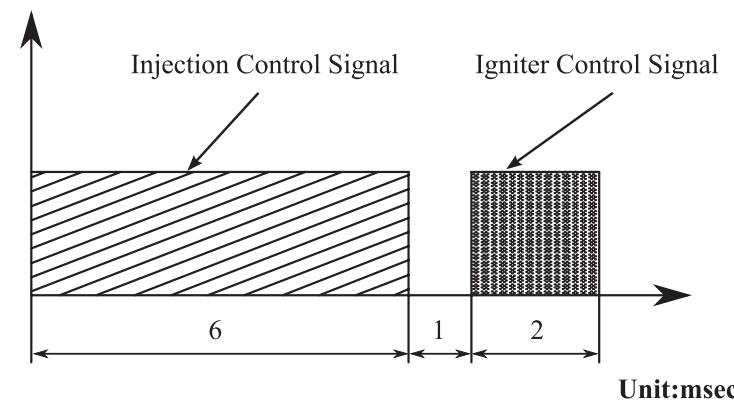

第 3 図 イグナイタ動作シーケンス

に短絡しないように先端から $1.5 \mathrm{~mm}$ より下側はアルミナ で覆われている。イグナイタの印加電圧は約 $15 \mathrm{kV}$, 放電 エネルギーは約 $0.1 \mathrm{~J}$ である。また，第 3 図のようにイグ ナイタは，噴射器に作動信号を送信し終えてから $1 \mathrm{~ms}$ 後に 駆動を行っている.

2.3 インパルスビット測定装置 本実験にて, インパル スビット $I_{\mathrm{bit}}$ （インパルス状に発生する推力を力積で評価 したもの, $\mu \mathrm{Ns}$ ）の測定には, PPT と対向するように設置 されたスラストターゲットを使用している6). スラストター ゲットは，推進機のプルームがもつ運動量を振り子の運動 に変換する装置であり, 振り子の振幅により $I_{\mathrm{bit}}$ を評価す ることができる。 スラストターゲットは，複数の円環と円 錐を組み合わせることにより, その軸方向に向かった PPT のプルームはスラストターゲットの半径方向に向きを変え, 軸方向への運動量が 0 となるため, 正確にインパルスビッ トの測定を行うことができる装置である。インパルスビッ トとスラストターゲットの振り子の変位との関係は, 紐で 吊した錘をスラストターゲットに衝突させて, 衝突する直 前の錘の速度と衝突後の振り子の振動の振幅から予め求め ている.

2.4 パルスアーク放電電流および電圧の波形計測 パ ルスアーク放電電流と電圧は，ロゴスキーコイルと電圧プ ローブを用いて測定する。また, 時間変化から放電回路の インダクタンスと電気抵抗を算出する.

\section{3. 実 験 結 果}

\section{1 自発放電方式}

3.1 .1 作動可能な充電エネルギーの範囲 自発放電方式 の試作機では, 電極間距離 $G$ が $10 \mathrm{~mm}$ の場合, 電極長さ $l$ が $40,70 \mathrm{~mm}$ のとき充電エネルギー $E_{\mathrm{c}}$ が $7 \mathrm{~J}$ 以上でパ ルスアーク放電が誘起された. $l$ を $100 \mathrm{~mm}$ に伸ばすと $E_{\mathrm{c}}$ $=5 \mathrm{~J}$ 以上でも放電を誘起できた.

$l=40 \mathrm{~mm}$ のとき, $G=10 \mathrm{~mm}$ のとき $E_{\mathrm{c}}=7 \mathrm{~J}$ 以上 でパルスアーク放電を誘起できたが， $G=20 \mathrm{~mm}$ まで広 げると誘起には最低でも $9 \mathrm{~J}$ 以上の充電エネルギーが必要 となった， $G$ をさらに $30 \mathrm{~mm}$ まで伸ばすと，今回の最大 充電エネルギーである $13 \mathrm{~J}$ でもパルスアーク放電は誘起さ れなかった。

3.1 .2 インパルスビット 第 4 図に, 電極間距離 $G$ が $10 \mathrm{~mm}$ で, 異なる電極長さ $l$ におけるインパルスビット

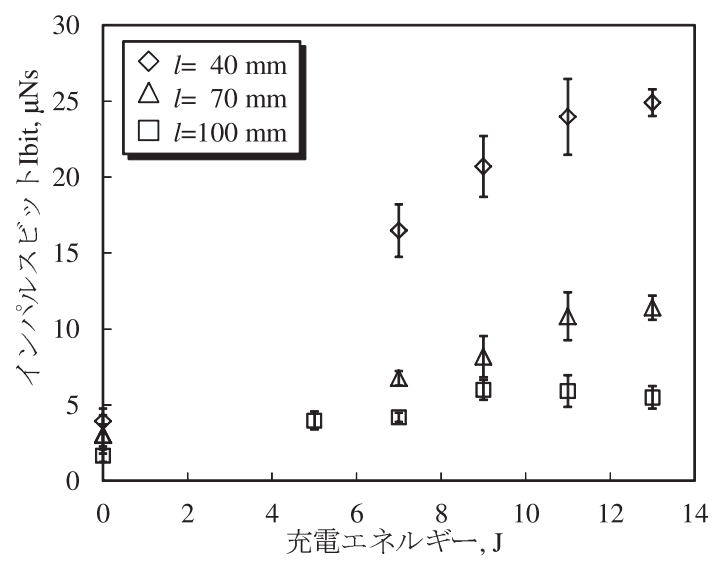

第 4 図 異なる電極長さ $l$ に対するときのインパルスビットと充電エ ネルギーの関係（電極間距離 $G=10 \mathrm{~mm}$ )

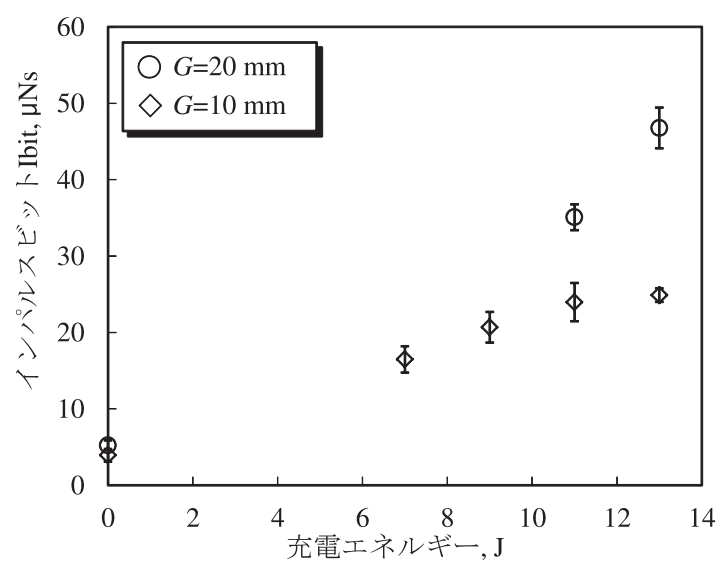

第 5 図 異なる電極間距離 $G$ に対するときのインパルスビットと充 電エネルギーの関係（電極長さ $l=40 \mathrm{~mm}$ )

$I_{\mathrm{bit}}$ と充電エネルギー $E_{\mathrm{c}}$ の関係を示す. 自発放電方式の 試作機においては， $E_{\mathrm{c}}$ の増加とともに $I_{\mathrm{bit}}$ が増加する様 子が示されている.

$I_{\mathrm{bit}}$ を与える理論式は, 次式で表される7).

$$
I_{\mathrm{bit}}=\frac{\mu G}{2 B R} E+\left[\frac{8(\gamma-1)}{\gamma^{2}(\gamma+1)} \cdot \Delta m \cdot W\right]^{\frac{1}{2}}
$$

第 1 項は，電磁加速によるインパルスビットを表現してお り電磁加速に使われたエネルギー $E$ に比例して変化する. 第 2 項は，電熱加速によるインパルスビットを表現してお り電熱加速に使われたエネルギー $W$ に対して 0.5 乗で増 加する。実験で得られた結果では，インパルスビットは充 電エネルギーにほほ比例して増加していることから, 今回 用いた平行平板型 DME-PPT では，電磁的加速が支配的 であると推測される。また， $l$ が短いほど，インパルスビッ トが大きく, $l=40 \mathrm{~mm} の I_{\mathrm{bit}}$ は, $l=100 \mathrm{~mm}$ の場合の 約 5 倍になっている.

第 5 図に, $l$ が $40 \mathrm{~mm}$ で異なる $G$ に対するインパルス ビットと充電エネルギーの関係を示す． $G$ を $10 \mathrm{~mm}$ から $20 \mathrm{~mm}$ に伸ばすと, インパルスビットが $1.5 \sim 2$ 倍高くなっ ていることが分かる. インパルスビットは, 理論上 (1) 式 


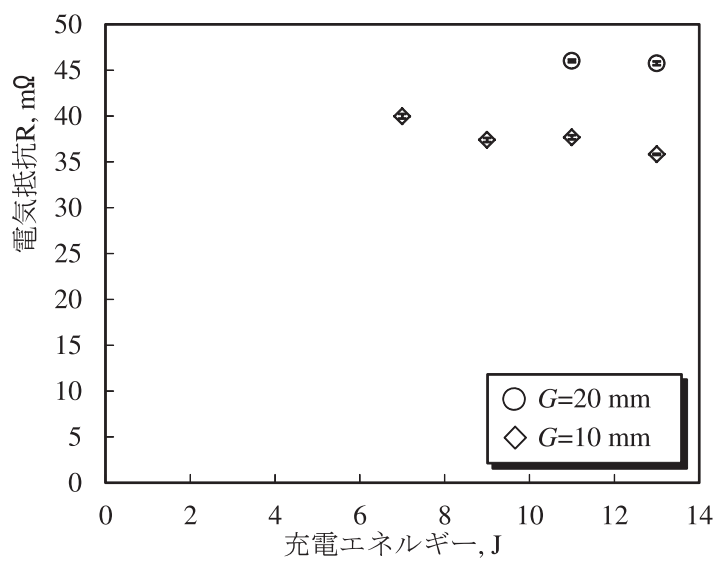

第 6 図 異なる電極間距離 $G$ に対するときの電気抵抗と充電エネル ギーの関係（電極長さ $l=40 \mathrm{~mm}$ )

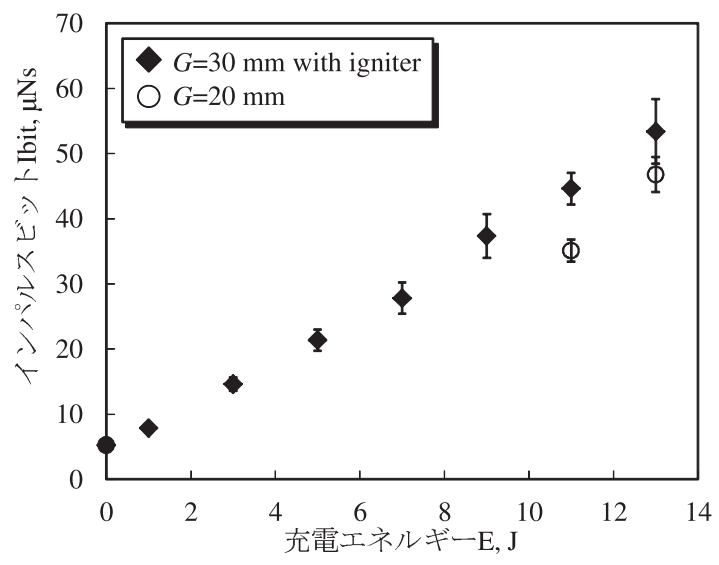

第 7 図 イグナイタ方式の場合のインパルスビットと充電エネルギー の関係 $(l=40 \mathrm{~mm}, \quad G=30 \mathrm{~mm})$

比較として自発放電方式 $(l=40 \mathrm{~mm}, G=20 \mathrm{~mm})$ の結 果も示す.

に示すように, $G$ に比例し, プラズマの電気抵抗 $R$ と電 極幅 $B$ に反比例する。 $R$ を, 放電電流波形から求めると 第 6 図のようになる。 $G$ と $B$ と第 6 図より, インパルス ビットは， $G$ を $10 \mathrm{~mm}$ から $20 \mathrm{~mm}$ に伸ばすことにより理 論上は 1.7 倍ほど増加することになる。これは, 先の実験 結果とほぼ一致している，すなわち， $G$ を増加することに より $R$ が増えたものの, $G / B$ が大きくなり, 全体として は, 電磁気力が強まり $I_{\mathrm{bit}}$ が増加したものと考えられる.

3.2 イグナイタ点火方式 第 7 図に, イグナイタ点火方 式を用い，電極長さ $l=40 \mathrm{~mm}$, 電極間距離 $G=30 \mathrm{~mm}$ として測定したインパルスビット $I_{\mathrm{bit}}$ と充電エネルギー $E_{\mathrm{c}}$ の関倸を示す。なお，比較のために自発放電方式を用いた ときの $l=40 \mathrm{~mm}, G=20 \mathrm{~mm}$ の結果も示している. イ グナイタを用いることにより自発放電方式ではパルスアー ク放電を誘起できなかった $G=30 \mathrm{~mm}$ に打いても作動が 可能となった，イグナイタ点火方式 DME-PPT において も, 自発放電方式と同様にインパルスビットと充電エネル ギーとの間には線形性がみられ電磁加速による推力が支配
的であると思われる。また，イグナイ夕点火方式は，自発 放電方式よりもすべての充電エネルギーにおいてインパル スビットが大きくなっている。これは，電極間距離 $G$ を 伸ばしてもイグナイタによりパルスアーク放電を誘起する ことができたためと考えられる。なお，イグナイ夕点火方 式では，今回の条件では， $E_{\mathrm{c}}$ が最も大きい $13 \mathrm{~J}$ のとき， インパルスビットと比推力が最大となり，それぞれ $53 \mu \mathrm{Ns}$, $200 \mathrm{~s}$ であった。

\section{4. ま ぬ め}

水やエタノールよりも貯蔵・供給が容易であるジメチル エーテルを推進剤として用いた平行平板型 DME-PPT の 試作機を用いた実験を行い次のような結果を得た。

・自発放電方式, イグナイ夕点火方式ともにパルスアーク 放電を誘起することができ, 再現性のある動作が可能で あった。

·自発放電方式では, 電極間距離 $G$ が広い場合や充電エネ ルギーが低い場合でのパルスアーク放電を誘起できない 現象が生じる。

・自発放電方式，イグナイタ方式のいずれの場合もインパ ルスビットは, 充電エネルギーに対して比例的に増加し ており，推進剤の加速に扔いて電磁気力が支配的である と考えられる。

・インパルスビットは, 電極間距離 $G$ を大きくするほど増 加した。これはインダクタンス空間勾配が増加したため と考えられる。

・今回の実験範囲においてのインパルスビット，比推力の 最大值は，それぞれ $53 \mu \mathrm{Ns}, 200 \mathrm{~s}$ であり，電極間距離 $G$ を大きくできるイグナイタ方式 DME-PPT における 充電エネルギー $E_{\mathrm{c}}=13 \mathrm{~J}$ のときであった.

\section{参 考 文 献}

1) Burton, R. L. and Turch, P. J.: Pulsed Plasma Thruster, J. Propul. Power, 14 (1998), pp. 716-735.

2) Spanjers, G. G., McFall, K. A., Gulczinski III, F. S. and Spores, R. A.: Investigation of Propellant in Efficiency in a Pulsed Plasma Thruster, Proc. of 32nd AIAA/ASME/SAE/ ASEE Joint Propulsion Conference, AIAA Paper 96-2723, 1996.

3) Spanjers, G. G., Lotspeich, J. S., McFall, K. A. and Spores, R. A.: Propellant Losses Because of Particulate Emission in a Pulsed Plasma Thruster, J. Propul. Power, 14 (1998), pp. $554-559$.

4) Kakami, A., Koizumi, H., Komurasaki, K. and Arakawa, Y.: Design and Performance of Liquid Propellant Pulsed Plasma Thruster, Vacuum, 73 (2004), pp. 419-425.

5) Masui, S., Okada, T., Kitatomi, M., Kakami, A. and Tachibana, T.: A Pulsed Plasma Thruster Using Dimethyl Ether as Propellant, Trans. JSASS, Aerospace Tech. Japan, 10 (2012), pp. Pb_65-Pb_69.

6) Yanagi, R. and Kimura. I.: New Type of Target for the Measurement of Impulse Bits of Pulsed Plasma Thruster, J. Spacecraft Rockets, 19 (1982), pp. 246-249.

7) 栗木恭一, 荒川義博: 電気推進機ロケット入門, 東京大学出版会, 東京, 2003 . 